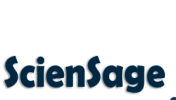

Journal of Advanced Scientific Research

Available online through https: / /sciensage.info
ISSN: 0976-9595

Research Article

DOI: $10.55218 /$ JASR.202213117

\title{
A STUDY ON CHARACTERIZATION OF PECTINASE ASSISTED AQUEOUS EXTRACTION OF RICE BRAN OIL
}

\author{
Gayathri Devi Selvaraju*, Dhanniya S, Kowsika S, Divyadharshini K, Harish T, Rachael Jayamani D \\ School of Biotechnology, Dr. G. R. Damodaran College of science (Autonomous), Coimbatore, TamilNadu, India \\ *Corresponding author: gayu.bt14@gmail.com
}

\begin{abstract}
The Rice bran oil is known as wonder oil because of its numerous health benefits. It has a number of advantages over other edible oils because of the presence of antioxidant known as oryzanol. The rice bran contains 10-26\% oil depending on the factors like variety, milling process, and other conditions. Various solvents are currently used for rice bran oil extraction process at industrial sectors. These solvents are carcinogenic and also cause adverse effects to the environment. The enzyme-assisted aqueous extraction process has been regarded as an eco-friendly process. Pectinase enzyme is used to break down complex carbohydrates like pectin present in rice bran and allows easy oil extraction in aqueous solution. The present study aims to perform the aqueous extraction of rice bran oil using crude pectinase enzyme extracted from the pectinase producing bacteria Bacillus paramycoides and to study the oil characteristics. Out of the various solvents used in the study, hexane yielded highest percentage of oil. The oil yield was found to be $49.8 \%$ in 6 h. The total activity of enzyme was found to be $11 \mathrm{U} / \mathrm{mL} / \mathrm{min}$. 500 Units of enzyme was taken for rice bran oil extraction. The Average yield of oil was found to be $80.5 \%$ in $3 \mathrm{~h}$ and $76.9 \%$ in $6 \mathrm{~h}$. The acid value, saponification value, iodine value and oryzanol content of the oil was found to be11.22, 84.15, 5.0 and 0.05 percentage respectively. The percentage of radical scavenging activity of the extracted rice bran oil was found to be $49.51 \%$. The fatty acids present in the oil sample were analyzed by GC MS analysis.
\end{abstract}

Keywords: Rice bran oil, aqueous extraction, pectinase enzyme, Bacillus paramycoides, radical scavenging activity and GC MS analysis.

\section{INTRODUCTION}

The rice bran oil is known as a miracle of all edible oils because of its numerous health benefits. It has a various advantage over other edible oils because of the presence of high amount of antioxidant known as oryzanol [1]. It is a unique product obtained from the outer layer of the brown rice. It is widely used in food, pharmaceutical and chemical industry because of its antioxidant properties and other medicinal and nutritional values. There is a huge interest in the use of rice bran oil for health and allied products because of the demand for natural products [2]. It is a rich source of PUFA (polyunsaturated fatty acid) which gives it a potential antioxidant and nutraceutical property.

There are many techniques employed for the extraction of rice bran oil previously in other reports. Those include supercritical carbon dioxide fluid extraction [3], compressed liquefied petroleum gas [4], ultrasoundassisted aqueous extraction [5], sub-critical water extraction techniques [6], ultrasonic enzymatic extraction, microwave-assisted extraction [7], subcritical carbon dioxide and soxhlet extraction [8]. Though many methods are employed, solvent extraction is widely used for extraction of rice bran oil [9]. Solvent extraction method can be used to recover oil from any substrates [10]. Hexane is the most commonly used solvent for solvent extraction method because of its high oil yielding property [11].

Though the solvent hexane is widely used for rice bran oil extraction, it is however flammable, volatile, toxic, carcinogenic and also cause environmental hazard [12]. It is also considered undesirable to human consumption because of its carcinogenic nature. The enzyme-assisted aqueous extraction technology has been regarded as an eco-friendly process to obtain a good quality of rice bran oil [13]. The use of aqueous medium for extraction of oil from various oil seeds has been reported by previous studies [14]. Aqueous medium has been reported efficient 
for extraction of corn germ [15], soybean [16], peanut [17], sunflower [18] and rice bran oil [19]. The enzymatic extraction increases the productivity, efficiency and antioxidant properties of rice bran oil. Enzymes have the ability to enhance extraction processes and eliminate other toxic and anti-nutritional factors. It also catalyzes the conversion of complex carbohydrate, protein and lipid to simpler byproducts through their biocatalytic activities [18]. The enzymatic process helps to hydrolyze and degrade the complex polysaccharides present in the cell wall of the rice bran leading to the release of high quantity of oil into the aqueous solvent. The enzymatic hydrolysis was performed using various enzymes like cellulose, protease and amylase previously. This method produces a good quality rice bran oil with attributes such as color, free fatty acids, peroxide value, and phosphorus contents [20]. Pectinase is the enzyme that breaks down the complex polysaccharide pectin into simple monosaccharides. Cell wall of rice bran is a rich source of the carbohydrate pectin. Use of pectinase enzyme breaks the pectin into simple sugars and this aid in the efficient extraction of rice bran oil.

The present study aims to extract rice bran oil using common solvents like ethanol, hexane, commercial pectinases and the crude pectinase enzyme isolated from the bacteria Bacillus paramycoides. The oil yield of crude pectinases is compared with the commercially available pectinase enzyme and also the common solvents. The fatty acid composition of the extracted oil is analyzed by GC-MS analysis.

\section{MATERIAL AND METHODS}

\subsection{Extraction of rice bran oil using various solvents}

Rice bran was sieved and heated at $100^{\circ} \mathrm{C}$ for $15 \mathrm{~min}$. For $20 \mathrm{~g}$ of rice bran, $100 \mathrm{ml}$ ethanol, hydro ethanol, hexane and water was added. It was then incubated in shaker for 3 and $6 \mathrm{~h}(160 \mathrm{rpm})$ at $50^{\circ} \mathrm{C}$. The sample was filtered by Whatmann no.1 filter paper and the solvents were evaporated under vacuum. The weight of the obtained oil sample was determined. Oil percentage recovery was calculated using the formula: Yield $\%=$ (mean weight of oil extract/mean weight of rice bran) X 100.

\subsection{Extraction of rice bran oil using commercial pectinase}

Rice bran oil was mixed with 100U, 200U, 300U, 400U, $500 \mathrm{U}$ of commercial pectinase enzyme (Himedia Laboratories Pvt Ltd.,) in the ratio 1:5. The mixture was incubated in a shaker at $25^{\circ} \mathrm{C}$ for $3 \mathrm{~h}$ and $6 \mathrm{~h}$ and filtered by Whatmann no.1 filter paper. The solvents were evaporated under vacuum. Percentage of oil yield was calculated using the above formula.

\subsection{Sub culturing of pectinase producing bacteria-Bacillus paramycoides and production of crude enzyme}

The bacteria Bacillus paramycoides which was reported to produce pectinase enzyme was sub cultured in Luria Bertanni media, incubated at $37^{\circ} \mathrm{C}$ over night and then stored at $4^{\circ} \mathrm{C}$. The bacteria were screened for pectinase production using submerged fermentation in the production medium. The pure cultures were inoculated in $10 \%$ inoculum at $37^{\circ} \mathrm{C}$ for $24 \mathrm{~h}$, then transferred into $90.0 \mathrm{ml}$ fermentation medium, and incubated at $37^{\circ} \mathrm{C}$ for 24h. After incubation, biomass was separated by centrifugation at $6000 \mathrm{rpm}$ for $15 \mathrm{~min}$. The supernatant was used to evaluate pectinase activity.

\subsection{Estimation of pectinase activity}

Crude pectinase enzyme $(0.5 \mathrm{~mL})$ and $0.5 \mathrm{~mL}$ of pectin ( $1 \%$ pectin in $0.1 \mathrm{M}$ acetate buffer $\mathrm{pH}-6$ ) was incubated at $37^{\circ} \mathrm{C}$ for $10 \mathrm{~min}$, and the tubes were boiled at $90^{\circ} \mathrm{C}$ for 5 min and $0.1 \mathrm{~mL}$ of the sample was taken for Dinitro Salicylic Acid assay. One Unit of enzyme activity was found to be one micromoles of glucose released per $\mathrm{mL}$ of sample per minute.

\subsection{Extraction of rice bran oil using crude pectinase enzyme}

$500 \mathrm{U}$ of isolated crude enzyme was dissolved in $50 \mathrm{ml}$ of acetate buffer of $\mathrm{pH} 4$, and mixed with rice bran in the ratio $1: 5$ and incubated at $37^{\circ} \mathrm{C}$ for 3 and $6 \mathrm{hrs}$. The mixture was then filtered and the extract was centrifuged for 20 minutes at 4000rpm. It was then evaporated using water bath and yield of the oil was calculated using the above formula.

\subsection{Determination of Oil Characteristics}

\subsubsection{Acid Value}

One $g$ of oil was weighed accurately and taken in a $250 \mathrm{ml}$ conical flask. It was dissolved in $150 \mathrm{ml}$ of solvent mixture (mixture of ethanol and ether) and mixed well. One drop of phenolphthalein was added and the mixture was titrated against the standard solution of $\mathrm{KOH}$ until the pink color disappears. Volume of $\mathrm{KOH}$ used was recorded and acid value was calculated. 


\subsubsection{Iodine Value}

Appropriate quantity of oil was taken in $250 \mathrm{ml}$ of conical flask and mixed in $15 \mathrm{ml}$ carbon tetrachloride. $25 \mathrm{ml}$ of Wijs solution was added from the burette to the mixture. The flask was allowed to stand in dark for $20 \mathrm{~min} .25 \mathrm{ml}$ of potassium iodide solution and $150 \mathrm{ml}$ of water was added to the solution. It was then titrated with standard $0.5 \mathrm{M}$ sodium thiosulphate solution, using starch solution as indicator. Titration was continued until the colour disappears. Value of $\mathrm{Na}_{2} \mathrm{~S}_{2} \mathrm{O}_{3}$ used was recorded.

\subsubsection{Saponification value}

One $g$ of oil was weighed in $250 \mathrm{ml}$ conical flask. Ester was dissolved in $25 \mathrm{ml}$ ethanol and $\mathrm{KOH}$ was added to the solution with the help of pipette. The flasks were heated in water bath for about 1 hour with occasional shaking. To the hot solution, one drop of phenolphthalein was added and titrated with standard $0.5 \mathrm{M} \mathrm{HCl}$ until the colour of indicator changes. Volume of $\mathrm{HCl}$ used was recorded.

\subsubsection{Gamma Oryzanol content}

A $0.5 \mathrm{~g}$ of oil was dissolved in $1 \mathrm{ml}$ of $\mathrm{n}$-heptane and absorbance was taken in UV-spectrophotometer at 315 nm. n-heptane was taken as a control. The amount of oryzanol content was calculated as follows: Oryzanol $(\mathrm{ppm})=\mathrm{O} . \mathrm{D} \times 25-359 \times 0.055$.

\subsection{Determination of Radical Scavenging Activity of the rice bran oil}

Radical Scavenging activity was determined by DPPH Assay. $3.9 \mathrm{ml}$ of DPPH was dissolved in methanol. $10 \mu \mathrm{l}$ of oil was mixed with $3.9 \mathrm{ml}$ of DPPH solution. DPPH without oil was taken as control. It was incubated for 30 min and absorbance was measured at $515 \mathrm{~nm}$. Percentage of radical scavenging activity was calculated as

$\{($ Ab blank - Ab sample $) /$ Ab blank $\} \times 100$

\subsection{Gas Chromatography Mass Spectrometry (GC MS) ANALYSIS}

The components present in the rice bran oil extracted using the crude enzyme was estimated by GC MS analysis.

\section{RESULTS}

\subsection{Extraction of rice bran oil using various solvents}

Hexane yielded highest percentage of oil when compared to other solvents. The oil yield was found to be $63.7 \%$ in $3 \mathrm{~h}$ and $49.8 \%$ in $6 \mathrm{~h}$ (Table 1 ).
Table 1: Average Yield \% of rice bran oil using various solvents

\begin{tabular}{ccc}
\hline \multirow{2}{*}{ Solvent } & \multicolumn{2}{c}{ Average Oil Yield (\%) } \\
\cline { 2 - 3 } & $\mathbf{3} \mathbf{~ h}$ & $\mathbf{6 ~ h}$ \\
\hline Hexane & $\mathbf{9 3 . 7 \pm 0 . 9}$ & $\mathbf{8 9 . 8} \pm 1.3$ \\
\hline Ethanol & $48 \pm 0.8$ & $36.8 \pm 1.1$ \\
\hline Hydroethanol & $19.2 \pm 1.2$ & $9.3 \pm 0.9$ \\
\hline Water & $1.74 \pm 1.2$ & $1.36 \pm 0.8$ \\
\hline
\end{tabular}

\subsection{Extraction of rice bran oil using commercial pectinase}

Rice bran oil extraction was done using different units of commercially available pectinase enzyme. The results showed that $500 \mathrm{U}$ of enzyme yielded highest oil yield of about $89.9 \%$ in $3 \mathrm{~h}$ and $85.1 \%$ in $6 \mathrm{~h}$ (Table 2).

Table 2: Average Yield \% of rice bran oil using commercial pectinase enzyme

\begin{tabular}{ccc}
\hline $\begin{array}{c}\text { Commercial pectinase } \\
\text { enzyme (U) }\end{array}$ & \multicolumn{2}{c}{ Average Oil Yield (\%) } \\
\cline { 2 - 3 } $\mathbf{3 ~ h}$ & $\mathbf{6 ~ h}$ \\
\hline 100 & $53.9 \pm 0.7$ & $61.2 \pm 0.9$ \\
\hline 200 & $81.5 \pm 0.8$ & $80.4 \pm 0.8$ \\
\hline 300 & $82.5 \pm 0.9$ & $80.7 \pm 1.0$ \\
\hline 400 & $89.9 \pm 0.7$ & $76.0 \pm 1.1$ \\
\hline 500 & $89.9 \pm 0.6$ & $85.1 \pm 1.2$ \\
\hline
\end{tabular}

\subsection{Estimation of total activity of enzyme by} dinitrosalicilylic acid method

The crude enzyme was extracted from the previously isolated pectinase producing bacteria Bacillus paramycoides (NCBI Accession number: MT131296) The total activity of enzyme using DNSA method was found to be 11 $\mathrm{U} / \mathrm{mL} / \mathrm{min}$.

\subsection{Extraction of rice bran oil using crude pectinase enzyme}

500 Units of enzyme was taken for rice bran oil extraction. The average yield of oil was found to be $80.5 \%$ in $3 \mathrm{~h}$ and $76.9 \%$ in $6 \mathrm{~h}$ (Table 3). The yield was comparable to oil extracted using commercially available pectinase enzyme and also hexane (Fig. 1).

Table 3: Average Yield \% of rice bran oil using crude pectinase enzyme isolated from bacteria

\begin{tabular}{ccc}
\hline $\begin{array}{c}\text { Extraction } \\
\text { time }\end{array}$ & $\begin{array}{c}\text { Enzyme units } \\
\text { taken }\end{array}$ & $\begin{array}{c}\text { Average yield } \\
\text { of oil (\%) }\end{array}$ \\
\hline $3 \mathrm{~h}$ & 500 & $80.5 \pm 1.2$ \\
\hline $6 \mathrm{~h}$ & 500 & $76.9 \pm 1.0$ \\
\hline
\end{tabular}




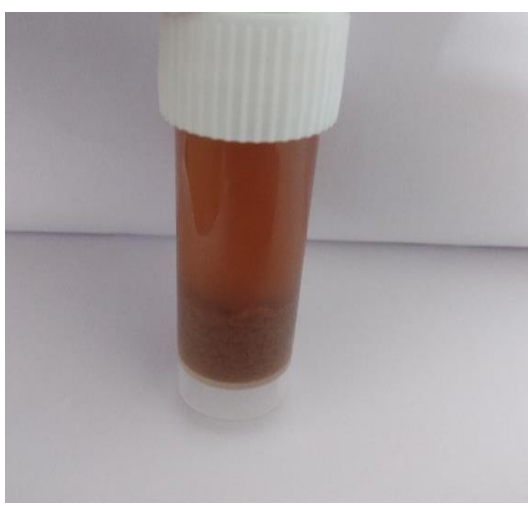

Fig. 1: Ricebran oil extracted using crude pectinases obtained from pectinase producing bacteria Bacillus paramycoides

\subsection{Determination of oil characteristics}

The acid value, saponification value, iodine value and oryzanol content of the extracted rice bran oil was found to be $11.22,84.15,5.0$ and 0.05 respectively.

\subsection{Determination of Anti-oxidant activity of oil by DPPH assay}

The percentage of Radical Scavenging activity of the extracted rice bran oil was found to be $49.51 \%$.

\subsection{GC-MS Analysis}

Upon GC MS analysis, the major peaks represented the presence of fatty acids like palmitic acid, linoleic acid, octa decanoic acid etc., (Table 4), (Figure 2).

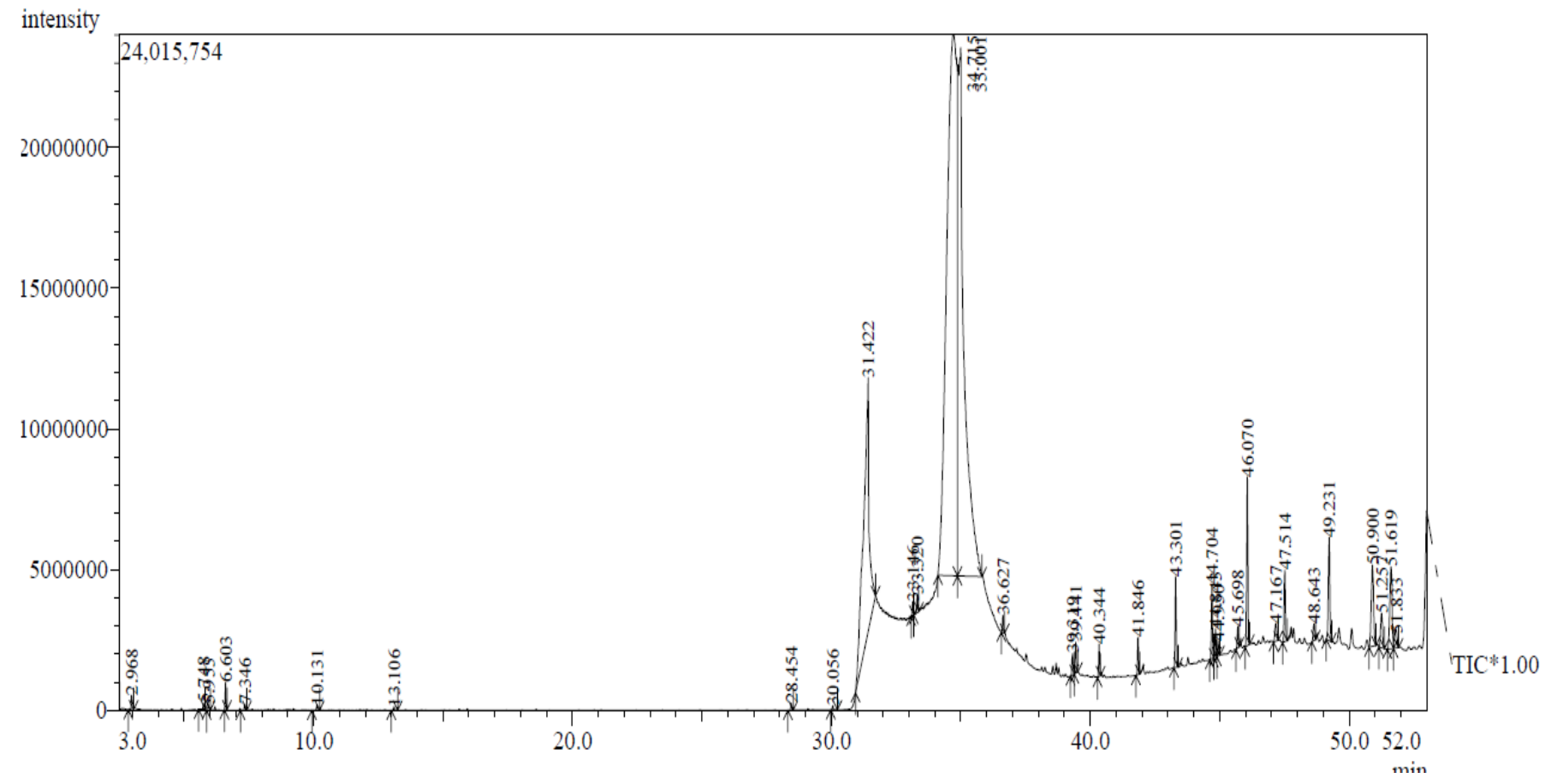

Fig. 2: GC MS peaks of Rice bran oil sample

Table 4: Fatty acids obtained by GC-MS analysis

\begin{tabular}{cc}
\hline Retention time & Fatty acids \\
\hline 30.058 & Palmitic acid \\
\hline 31.425 & Palmitic acid \\
\hline 33.142 & Linoleic acid \\
\hline 34.717 & Linoleic acid \\
\hline 35.00 & Octadecanoic acid \\
\hline
\end{tabular}

\section{DISCUSSION}

Rice bran oil is used as a high-quality cooking oil, whereas crude bran oil has been used for soap manufacture and also for the production of industrial fatty acids. The cell wall of plant cells is composed of complex polysaccharides like cellulose, hemicelluloses, lignin and pectin. Hydrolytic enzymes such as cellulases, hemicellulase and pectinases can break down the cell wall and facilitate release of oil from the rice bran. Thus, in enzyme-assisted aqueous extraction, the soluble components of the rice bran can diffuse into water. The released rice bran oil forms a separate phase and leads to better oil recovery [4]. Enzyme-based aqueous extraction has been previously employed to recovery of high-quality oil from coconut, soy bean and corn germ by using enzymes like pectinase, amylases, 
and proteases giving oil recovery in the range of 90 $98 \%$.

The enzymatic process improved the quality of extracted oil by increasing the content of other bioactive compounds, such as phenolics and carotenoids. Other authors have reported the successful use of enzymes in the extraction of oil from substrates other than rice bran [21]. All their results confirmed that the use of mixture of enzymes improves the extractability of oil from oil bearing materials, over single enzymes. Addition of pectinase to the aqueous extraction medium enhanced oil extraction at the various conditions due to their degrading action upon the cell walls which are composed of high quantity of pectin. So, it could be concluded that pectinase helped to break the links between oil molecules and aids in efficient oil extraction.

DPPH is a stable free radical which shows a maximum absorbance at $515 \mathrm{~nm}$. It can readily reduce upon addition of antioxidants thus it is used in determination of free radical scavenging ability. This test showed that rice bran oil extracted using pectinase had a maximum antioxidant activity. GCMS analysis showed the presence of major fatty acids which would be present in rice bran oil. This proves that aqueous extraction using pectinases from Bacillus paramycoides could efficiently extract rice bran oil.

\section{CONCLUSION}

The pectinase enzyme was used in the study to enhance the rice bran oil production and it gave a high yield of about $80 \%$ in a short time of 3 hours when compared to the conventional processes. It is also an ecofriendly approach which does not produce any hazardous byproducts. The same enzymatic method involving pectinase enzyme could also be used for other starch rich substrates in oil industries. The use of pectinase enzyme has the potential to increase productivity, efficiency and quality of rice bran oil. It requires low capital investment and relatively small amount of energy consumption unlike other methods of oil recovery. Despite these advantages, this enzymatic method is still restricted to laboratory - scale studies. So, it has to be completely explored in order to be ventured to scale-up studies and thus, this enzymatic method of rice bran oil extraction would be a bloom to the industries in near future.

\section{Conflict of interest}

The authors declare that no conflict of interest exists.

\section{REFERENCES}

1. Nayik AG, Majid I, Gull A, Muzaffar K. Rice Reasearch, 2015; 3(4):4-6.

2. Dominguez H, Nlikz MJ, Lema JM. Food Chemistry, 1995; 53(4): 427-434.

3. Khoei M, Chekin F. Food Chemistry, 2016; 194: 503 507.

4. Soares JF, Dal Pra V, De Souza M, Lunelli FC, Abaide E, Da Silva JR, et al. Journal of Food Engineering, 2016; 170: 58-63.

5. Krishnan, VCA, Kuriakose S, Rawson A. Journal of Food Processing \& Technology, 2015; 6(6): 454.

6. Pourali O, Salak Asghari F, Yoshida H. Journal of Food Engineering, 2009; 95(3): 510-516.

7. Zigoneanu IG, Williams L, Xu Z, Sabliov CM. Bioresources Technology, 2008; 99(11): 4910-4918.

8. Chai SL, Boo HC, Muhamad K, Sulaiman R, Umanan F, Chong GH. Journal of the American Oil Chemists' Society, 2015; 92(3):393-402.

9. Liu HM, Wang FY, Li HY, Wang XDM, Qin GY. Bioresources, 2015; 10(3): 4652-4662.

10. $\mathrm{Xu} \mathrm{Z,} \mathrm{Godber} \mathrm{JS.} \mathrm{Journal} \mathrm{of} \mathrm{the} \mathrm{American} \mathrm{Oil}$ Chemists' Society, 2000; 77(5):547-551.

11. Sparks D, Hernandez R, Zappi M, Blackwell D, Flemings T. Journal of the American Oil Chemists' Society, 2006; 83(10):10-16.

12. Balachandran C, Mayamol PN, Thomas S, Sukumar D, Sundaresan A, Arumughan C. Bioresource Technology, 2008; 99(8):2905-2912.

13. Nandi S, Bhattacharyya R. International Journal on Recent and Innovation Trends in Computing and Communication, 2015; (2):21-25.

14. Fang X, Moreau RA. Journal of American Oil Chemists' Society, 2014; 91(7):1261-1268.

15. Moreau RA, Dickey LC, Johnston DB, Hicks KB. Journal of the American Oil Chemists 'Society, 2009; 86(5): 469-474.

16. Campbell KA, Glatz CE. Biotechnology Process, 2010; 26(2): 488-495.

17. Zhang SB, Lu QY, Yang Li Y, Wang S. Journal of American Oil Chemists' Society, 2011; 88(5):727-732.

18. Latif S, Anwar F. Journal of American Oil Chemists Society, 2009; 86(4):393 -400.

19. Fang X, Moreau RA. Journal of the American Oil Chemists' Society, 2014; 91(7):1261-1268.

20. Sharma A, Khare SK, Gupta MN. Journal of American Oil Chemists' Society, 2001; 78(9):949-951.

21. Seung Ho KIM. Journal of Food Science, 1989; 54(2):491-492. 